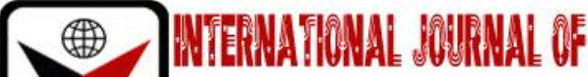

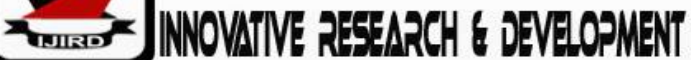

ISSN 2278-0211 (Online)

\section{Effectiveness of Teaching Practice Program on Development of Competence and Marketability of University Graduates in Moshi Rural Tanzania}

Ismail Yahya Kasaku
Student, Department of Education, Mwenge Catholic University, Tanzania
Amembah A Lamu Amos
Lecturer, Department of Business (Marketing Management),
Mwenge Catholic University, Tanzania
Bahiya Abdi
Assistant Lecturer, Department of Education, Mwenge Catholic University, Tanzania
Blandina Kori B Walowe
Assistant Lecturer, Department of Business, Mwenge Catholic University, Tanzania

\begin{abstract}
:
The aim of the study was to investigate on the Effectiveness of teaching practice program on the development of competence and marketability among university graduates. The study employed mixed research approach where explanatory sequential design was used that included both quantitative and qualitative data collection. The respondents included was 100 second-and third-year university student teachers from Mwenge Catholic University (MWECAU), thirty (30) university graduates, one (1) teaching practice coordinator and either Eight (8) headmasters or headmistress or eight (8) academic teachers (academic master or mistress to both government, private and community secondary schools in Moshi rural. Data was collected through questionnaire and structured interview schedule. The data was then analyzed through: percentages, frequencies, means and themes. The analysis of the of the findings reveal that teaching practice programs contribute much to the development competence and marketability of the university graduates. Therefore, both governments and universities should develop and implement effective teaching practice strategies, methods and tools in order to produce competent teachers that meet the market needs and market competition.
\end{abstract}

Keywords: Marketability, competency, skills, teaching practice and market needs

\section{Introduction}

Market needs in the education sector requires that the teacher who is the main player in developing, implementing and evaluating the teaching process (curriculum); ought to be competent as well marketable. Therefore, all teaching programs have a component of teaching practice which a process through which the student teacher undertake to develop their competencies and marketability for the market. Teaching practice still remains of the greatest importance in the world today. The success of a teaching practice program is dependent on the quality and quantity of professional training of the teachers. The quality develops opportunities to acquire competencies needed for effective teaching, impacting or transferring knowledge, assisting those being taught to be aware of their talents, have more knowledge and how to use their skills and competencies in the marketplace.

In education adequate preparation (teaching practice) of the student teachers for his task is very important Teaching practice is meant to provide for authentic context whereby student teachers are exposed to experience the complexities and richness of the reality of being a teacher. This process allows the student teacher to establish whether the right career choice has been made or not. However, despite its importance, Kiggundu and Nayimuli (2009) noted that teaching practice sometimes becomes a demoralizing and sometimes very frightening experience. The managing of the classroom to the student teacher during teaching practice depends much on the methods, skills, experiences and competencies employed by student teacher.

Conclusively, teaching practice is an important component in the process of developing teachers. If the process is developed effectively it can make Student teachers to know the value of the teaching profession since it provides for the real interface between students and other members of the profession (Rakesh, 2013). 


\subsection{Statement of the Problem}

Universities include the teaching practice module in order to prepare the student teachers to be marketable to industry despite the other modules that they undertake during the program. But having knowledge does not make a student marketable. The teaching practice program enables them to practically apply and develop that which has been taught in class (methodology, techniques, skills and ethics of education. Hence, a pre-service training prepares a person to be marketable for a teaching for a teaching career. The training enables the future teachers to comprehend education theories, knowledge, skills as well as gain social skills. Knowledge and skills are is different subjects with which to start with a successful teaching career. The student teacher is expected to master his or her area of specialization in order to be in the best position to help learners. There is agreement among scholars about the importance of the teacher and his or her competence in the teaching and learning process. The teacher is the heart of the classroom (URT, 2007). However, the teaching practice modules differ from one university to the other in terms of: goals, period, methods of assessment, evaluation, focus etc. which may have an influence on the competence and marketability of graduates. Therefore, this study conducted to access the effectiveness of teaching practice program on development of competence and marketability of university graduates in Moshi rural area.

\subsubsection{Research Questions}

- To what extent is the effectiveness of teaching practice programs toward development of competence and marketability of university graduates?

- What is the perception of employers toward the effectiveness of the teaching practice programs on the competence and skills development?

\subsubsection{Hypotheses}

- $\mathrm{H}_{1}$ : Teaching practice has a positive relationship on competence and marketability of university graduates

\subsection{Scope And Delimitation Of The Study}

The study was conducted in Moshi rural in Kilimanjaro region because this is the area where there is availability of student teachers and university graduates as well as schools which enabled the researcher to collect data and to come up with the solutions that helped university graduates to overcome the issue of marketability. Since this problem exist in almost the whole countries so Moshi rural is taken as the sample. In this study student teachers, university graduates and school administration like headmasters involved that enabled to collect data

\subsection{Theoretical Frame Work}

\subsubsection{Attribution Theory by Harold Kelley 1967}

This study was guided by Attribution theory developed by Kelley at 1967, He was an American social psychologist and professor of psychology at the University of California, Los Angeles. The psychologist Kelley's theory states that 'An effect is attributed to the one of its possible causes with which overtime it covaries' Kelley prepared the model that explain his theory and the model called Kelley conversation model, it is logical model for judging whether a particular action should be attributed to some characteristics (internal) of the person or the environment (external). The term conversation simply means a person that has information from multiple observations at different times and situations and can perceive the covariation of an observed effect and its effect.

It is argued that in trying to discover the cause of behavior, people act like scientists. The theory describes the processes and manner that we attribute causality of certain event to occur, this theory based much on logical judgment on why people do things by taking the records of different activities or events to what student teachers engage. Kelley explained that under logical judgment for one event to occur there must be another thing besides that cause it to occur. But this theory is useful when there is enough information. If the information is not sufficient it becomes very difficult to make judgment. This theory does not explain on how these logical judgments are made and how the problem can be solved by using these judgments, there is no alternatives after missing but it provides the way on how one thing can course another thing to occur only.

The is relevant because it creates and generates knowledge on how student teachers work in their teaching practice and keeping the records, that made their records available in preserved documents that can used later when there is need to get information of the graduates about teaching practice that can easily direct the school administration about general behavior before completion of the study on how he or she conducted her activities. Then two events were compared or judged the way teaching practice conducted by that graduates and the chance of him or her to be employed. If the graduates have good history from his or her teaching practice there is the maximum probability of being employed.

\subsubsection{Conceptual Frame Work}

According to Omari (2011), all researches are conceptual, it involves some imagination, some hypothetical thought, research questions and data collection instruments are directly derived from conceptual frame work. To consider effectiveness of teaching practice program on development of competence and marketability to university graduates hence this page shows some independent, intervenient and dependent variables and how relates to each other. 


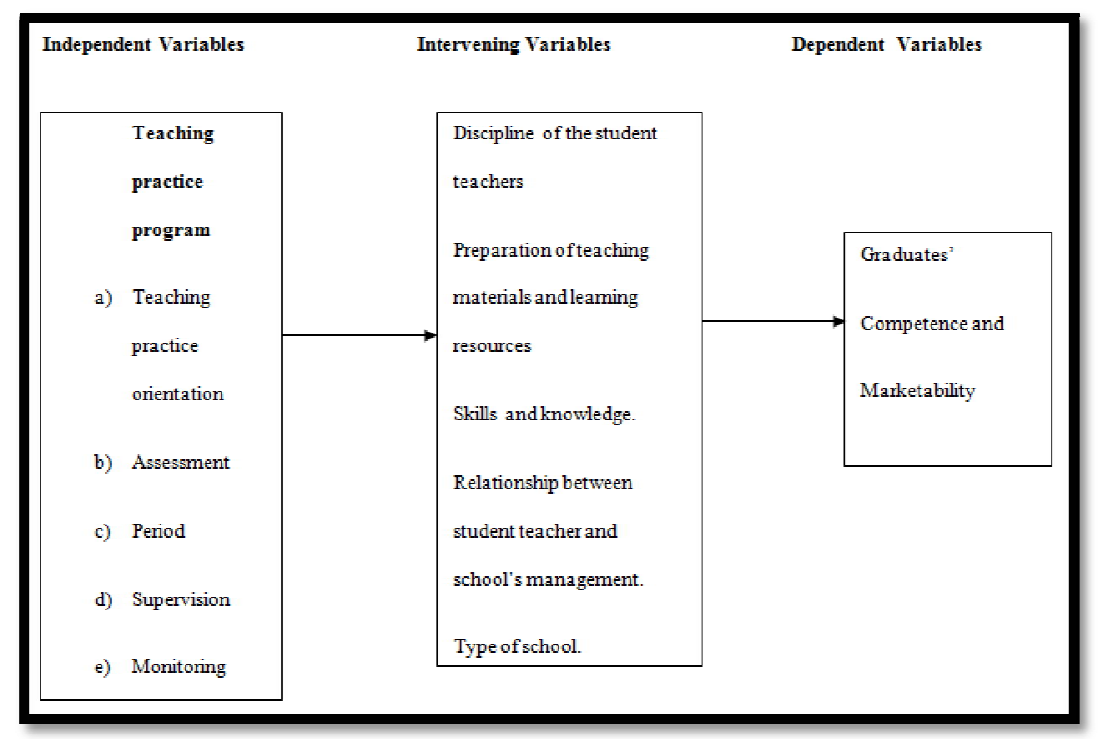

Figure 1: Researcher's Own Construction (2018)

\section{Literature Review}

Komba (2013), conducted a research on effectiveness of teaching practice in improving student teachers' skills in Tanzania. This study was designed to find out how teaching practice was organized by the teacher training universities and whether the teaching practice was effective in improving student teachers' skills and marketability. The qualitative research approach was adopted and the study was conducted in Iringa, Morogoro, Dar es Salaam and Kilimanjaro region of Tanzania mainland. A total of 191 student teachers were involved in the study where questionnaires were used for data collection. The findings indicated that the duration spent for the teaching practice was inadequate for student teachers to acquire the skills required for effective teaching. Furthermore, the supervision of student teachers during the teaching practice was overall ineffective as the supervisors were not flexible enough to guide, advice and discuss with student teachers on the strengths and weaknesses revealed during teaching. Therefore $76 \%$ of the respondents indicated that teaching practice was ineffective in improving their teaching skills. Since the majority of the respondents indicated that they did not benefit much from the teaching practice. However, the findings explained how teaching practice contributed much to the skills development but the researcher did not explain on how developed skills contributed to the marketability and competency of the university graduates.

Mohd (2015) conducted research on teaching practice in enhancing student teachers' competence at university of technology Mara at Malaysia. The study involved 20 students' teachers' sample were used to obtain data, the researcher surveyed on the teaching techniques, classroom observations in which he collected data by analyzing the nature of students and teacher interactions. The researcher found that competence should be viewed as the overall underlying knowledge and ability for language which the teacher and students possess, that means the concept of communicative competence lies around the level of knowledge. He proposed four sectors of communicative competence.

First, 'whether or not something is formally possible' refers to the skills and knowledge competence. Second 'whether something is feasible' deals with acceptability, third 'whether something is appropriate' that means what is taught or spoken should be appropriate to the context which it used, and finally whether something is fact done 'implies that is taught may be grammatically correct feasible and appropriate in context but have no probability of actual occurring. Speaking competently help in creating good impression, establishing health relationship. For student teachers it is very beneficial to help them maintaining good relationship with students that made them confident this helped them in their later stage of life when they have to deal with interviews and on set of career life. However, Mohd (2015), did not explain how effective teaching practice should be done in order to make those graduates competent. He also used few samples that is not enough to make a conclusion for the program because it may lead to biasness.

Zhao and Zhang (2017), conducted a research on the influence of teaching practice on pre-service teachers' professional identity in China. The study used mixed methods to research pre-service teachers' professional identity. Ninety-eight (98) pre-service teachers were investigated and twelve (12) teachers were interviewed. The results showed that, the quantitative data when compared before the field teaching practice of the pre-service teachers' professional identity, increased after the field teaching practice. The result of qualitative data validated and elaborated the results of quantitative data in more details with regard to change in professional identity. Before the field teaching practice, intrinsic value identity including work content, work patterns and other values increased and extrinsic value identity included work environment, income and social status which did not significantly change after experiencing the teaching practice time. The result of qualitative data also showed that mentor support at field school promoted the development of preservice teachers' professional identity. The development of pre-service teachers' professional identity during field teaching practice further promoted their professional commitment. The researcher found that, teachers with lower professional identity had a lower work satisfaction and higher work stress. However, the researchers explain on how professional teachers are developed from the teaching practice program to the pre-service teachers but they did not explain on how these identities facilitated the marketability the pre-service teachers after graduating. 
Bolarfinwa (2014), conducted a research on effect of teaching practice on student teachers in private schools' institutions in Nigeria. The case study included 400 student teachers in the department of Arts and Social Sciences of faculty at the University of Lagos. The study used three hypothesis and 100 questionnaires were administered to student teachers from the department of art and social science faculty of education and other 40 questionnaires administered to school administration officers like headmasters, headmistress and school managers. Analysis of the results obtained showed that teaching practice has never been a waste of time rather it has helped to inculcate professional traits in student teachers, thus preparing them to be competitive for the real classroom and market situations. The study also recommended that some form of assistance (finance and materials) should be given to the student teachers in order to facilitate their teaching practice activities. It also recommended that at least three weeks of grace should be given to student teachers to get used to the school system before an assessment done. Lastly adequate orientation should be given to student teachers before the teaching practice exercise. However, the researcher did not explain how competence is related to marketability.

Another study by, Awofala et al (2017), on the school administrators' perceptions of the employability of pre service science, Technology and Mathematics Teachers through Teaching practice in Nigeria examined Nigerian school administrators' perception of the skills central to the marketability of pre-service teachers. The aim of the study was to prepare the students to be ready and marketable. The study used a mixed method approach which offered an in depth, contextualized, and natural but more time-consuming insight of qualitative research. Data were collected using a semi structured interview (qualitative data) with a protocol that comprised four open ended questions involving 20 schools' administrators majorly principals and a survey comprised 39 five-pointed Likert scale statements (quantitative data) from 180 school administrators. The results showed a satisfactory level of pre service teachers' performance during the teaching practice as most administrators were in support of recruiting the pre service teachers in future. Teaching practice was ranked as the most important aspect next to personal attributes for enhancing employability aa well as improving the pre-service teachers. The school administrators perceived the duration of the teaching practice to be too short and suggested an extension to twelve months for pre service teachers to gain more experience and competence. However, the researchers explained well on how administrators perceive the student teachers but they dealt only with technology and Mathematic teachers while this problem also exists in other areas of professional subjects.

Mannathoko (2013), conducted a research on 'Does Teaching Practice Effectively Prepare Student-Teachers to Teach Creative and Performing Arts? In Botswana'. The study was conducted in three Colleges of Education located in the South East, Central and Francis town districts of Botswana. The participants were third year student-teachers and students who completed in colleges six to two years ago. The approach used was a qualitative case study. This method was adopted because 'it allows the researcher to interact with the subject of the research and therefore, enables the researcher to focus on complexities and qualities in educational action and interaction that might be difficult to attain through the use of standardized measures recommends qualitative studies with the view that smaller but focused samples are engaged in the study rather than large samples, to acquire thick descriptive data. Semi-structured interviews and case studies from student-teachers and practicing teachers were used to collect data. This qualitative study explored the extent to which teaching practice in primary Colleges of Education prepared student-teachers to teach Creative and Performing Arts subjects in primary schools. The findings revealed that student-teachers in the three Colleges of Education were introduced to the general pedagogy skills of teaching in primary schools by their tutors who in most cases were not arts specialists. There were concerns from student-teachers that lecturers rarely assessed the arts during teaching practice and therefore, trainees did not get any assistance to prepare them to teach the Creative and performing art subjects. Hence from the above findings' researchers managed to explain on how effective teaching practice influence to student teachers acquire general pedagogical skills while those who did not get assistance from the lecturers was less considered in the subject specialist but the study did not show how employers perceive teaching practice program instead the lecturers judged only about specialist of subjects to student teachers after teaching practice. Finally, the study did not consider the aspect of teaching practice with marketability and competence of the teacher students.

\section{Research Methodology}

The research employed a mixed methods approach whereby an explanatory sequential mixed design was used. The targeted populations were 1 university, -------student teachers, 98 head of schools and 98 academic master and one teaching practice coordinator. The study used stratified sampling technique to sample 100 student teachers and 8 schools. While researchers included 8 head of schools, 8 academic masters and one teaching practice coordinator automatically in the study. The data was collected using questionnaires and structured interview schedule these were administered to the: students, teachers and teaching practice coordinators. The reliability coefficient of the instrument was done by using Cronbach's Alpha method, for the student teachers' questionnaires and for academic master or mistresses' questionnaires, and the reliability become ranging from reliability coefficients of 0.5-0.9 hence it shows the instruments is reliable and meet the criteria. The data which was collected during the field survey was analyzed using SPSS program to give statistical data in terms of frequency, percentage and means.

\section{Results and Discussion}

The study aimed at finding out the extent to which teaching practice was effective in developing competence and marketability of university graduates in reference to Mwenge teaching practice program. Findings are presented in table 1 , 2 and 3. 


\begin{tabular}{|c|c|c|c|c|c|c|c|c|c|c|c|}
\hline \multirow[t]{2}{*}{ Items } & \multicolumn{2}{|c|}{ SA } & \multicolumn{2}{|c|}{ A } & \multicolumn{2}{|c|}{$\mathbf{U}$} & \multicolumn{2}{|c|}{ D } & \multicolumn{2}{|c|}{ SD } & \multirow[b]{2}{*}{ Mean } \\
\hline & f & $\%$ & f & $\%$ & f & $\%$ & f & $\%$ & f & $\%$ & \\
\hline $\begin{array}{l}\text { Mwenge teaching practice } \\
\text { program is effective. }\end{array}$ & 15 & 48.4 & 14 & 45.2 & 1 & 3.2 & 0 & 0.0 & 0 & 0.0 & 1.53 \\
\hline $\begin{array}{l}\text { Mwenge teaching practice } \\
\text { program is effective towards } \\
\text { creating competent teachers. }\end{array}$ & 16 & 51.6 & 12 & 38.7 & 1 & 3.2 & 1 & 3.2 & 0 & 0.0 & 1.57 \\
\hline $\begin{array}{l}\text { Mwenge teaching practice } \\
\text { program is effective toward } \\
\text { making student teacher } \\
\text { marketable. }\end{array}$ & 10 & 32.3 & 12 & 38.7 & 3 & 9.7 & 5 & 16.1 & 0 & 0.0 & 2.10 \\
\hline $\begin{array}{l}\text { The resource used in teaching } \\
\text { practice program are effective } \\
\text { toward creating competent } \\
\text { teachers. }\end{array}$ & 5 & 16.1 & 11 & 35.5 & 10 & 32.3 & 4 & 12.9 & 0 & 0.0 & 2.43 \\
\hline $\begin{array}{l}\text { The teaching practice program is } \\
\text { managed effective in creating } \\
\text { competence and marketability. }\end{array}$ & 6 & 19.4 & 11 & 35.5 & 7 & 22.6 & 6 & 19.4 & 0 & 0.0 & 2.43 \\
\hline $\begin{array}{l}\text { Teaching practice is supervised } \\
\text { effectively to create competence } \\
\text { and marketability of the student } \\
\text { teachers. }\end{array}$ & 6 & 19.4 & 15 & 48.4 & 5 & 16.1 & 3 & 9.7 & 1 & 3.2 & 2.27 \\
\hline $\begin{array}{c}\text { Teaching practice monitoring } \\
\text { program is managed effectively } \\
\text { to create competence and } \\
\text { marketability. }\end{array}$ & 4 & 12.9 & 13 & 41.9 & 3 & 9.7 & 9 & 29.0 & 1 & 3.2 & 2.67 \\
\hline $\begin{array}{l}\text { The time period of the teaching } \\
\text { practice program is allocated and } \\
\text { managed able to create } \\
\text { competence and marketability of } \\
\text { the student teachers. }\end{array}$ & 7 & 22.6 & 9 & 29.0 & 5 & 16.1 & 6 & 19.4 & 3 & 9.7 & 2.63 \\
\hline $\begin{array}{l}\text { Mwenge teaching practice } \\
\text { program creates opportunities } \\
\text { for job in the job market. }\end{array}$ & 7 & 22.6 & 16 & 51.6 & 3 & 9.7 & 4 & 12.9 & 0 & 0.0 & 2.13 \\
\hline
\end{tabular}

Table 1: Effectiveness of the Teaching Practice Program in Relation to Development of Competence and Marketability of University Graduates ( $N=30)$

Data: Field Data (2018)

Table 1 shows that (48.4\%) of the graduates strongly agreed that teaching practice program is effective while (3.2\%) were undecided. Further the data shows that (51.6\%) of employers strongly agreed that Mwenge teaching practice program was effective towards creating competent teachers while only $(3.3 \%)$ of graduates disagreed that Mwenge teaching practice program is not effective towards creating competent teachers. Also, $(38.70 \%)$ of the graduates agreed that Mwenge teaching practice program was effective towards making the student teacher marketable while (16.1\%) indicated that the program does not make student teachers marketable. The highest mean was (2.67) show that teaching practice monitoring program needs to be managed more effectively to create competent and marketable students. Similarly, to (Zhao and Zhang, 2018), found that teachers with lower professional identity easily perceive lower work satisfaction and higher work stress while higher professional identity teachers had a higher work satisfaction with lower work stress that was identified during teaching practice. Hence poor supervision of teaching practice program resulted to less professional identity. The implication of this finding is that, since most of the graduates indicated that Mwenge teaching practice is effectively conducted which enabled them to be highly marketable. The data also shows that $41.9 \%$ of the graduates indicated that teaching practice monitoring program is managed effectively to create competence and marketability while $3.2 \%$ disagreed. $51.6 \%$ of the graduates agreed that teaching practice program creates opportunities for job in the job market, similarly to Mohd (2015) who found that competence should be viewed as the overall underlying knowledge and ability for language which the teachers and students should possess. In these findings, it should be noted that the teaching practice program has greater impact on the job findings due to experience acquired which makes a person become different in the way they express themselves to employers professionally when presenting a lesson.

To investigate the effectiveness of teaching practice program in relation to the development of competence and marketability of the university graduates, employers were rated since they had the information due to their relationship with the student teachers at the school as shown in the Table 2. 


\begin{tabular}{|c|c|c|c|c|c|c|c|c|c|c|c|}
\hline \multirow[t]{2}{*}{ Items } & \multicolumn{2}{|c|}{ SA } & \multicolumn{2}{|c|}{ A } & \multicolumn{2}{|c|}{$\mathbf{U}$} & \multicolumn{2}{|c|}{ D } & \multicolumn{2}{|c|}{ SD } & \multirow[b]{2}{*}{ Mean } \\
\hline & $\mathbf{f}$ & $\%$ & $F$ & $\%$ & $\mathbf{F}$ & $\%$ & $\mathbf{F}$ & $\%$ & f & $\%$ & \\
\hline $\begin{array}{c}\text { Our teaching practice is } \\
\text { effective }\end{array}$ & 2 & 25.0 & 6 & 75.0 & 0 & 0.0 & 0 & 0.0 & 0 & 0.0 & 1.75 \\
\hline $\begin{array}{l}\text { Our teaching practice } \\
\text { program is effective towards } \\
\text { creating competent teachers }\end{array}$ & 3 & 37.5 & 5 & 62.5 & 0 & 0.0 & 0 & 0.0 & 0 & 0.0 & 1.63 \\
\hline $\begin{array}{l}\text { Our teaching practice } \\
\text { program is effective toward } \\
\text { making student teacher } \\
\text { marketable }\end{array}$ & 4 & 50.0 & 4 & 50.0 & 0 & 0.0 & 0 & 0.0 & 0 & 0.0 & 1.50 \\
\hline $\begin{array}{c}\text { The resource used in teaching } \\
\text { practice program are effective } \\
\text { toward creating competent } \\
\text { teachers }\end{array}$ & 1 & 12.5 & 7 & 87.5 & 0 & 0.0 & 0 & 0.0 & 0 & 0.0 & 1.88 \\
\hline $\begin{array}{c}\text { The teaching practice } \\
\text { program is managed effective } \\
\text { in creating competence and } \\
\text { marketability }\end{array}$ & 1 & 12.5 & 7 & 87.5 & 0 & 0.0 & 0 & 0.0 & 0 & 0.0 & 1.88 \\
\hline $\begin{array}{c}\text { Teaching practice is } \\
\text { supervised effectively to } \\
\text { create competence and } \\
\text { marketability of the student } \\
\text { teachers }\end{array}$ & 2 & 25.0 & 6 & 75.0 & 0 & 0.0 & 0 & 0.0 & 0 & 0.0 & 1.75 \\
\hline $\begin{array}{c}\text { Teaching practice monitoring } \\
\text { program is managed } \\
\text { effectively to create } \\
\text { competence and } \\
\text { marketability. }\end{array}$ & 1 & 12.5 & 5 & 62.5 & 0 & 0.0 & 2 & 25.0 & 0 & 0.0 & 2.38 \\
\hline $\begin{array}{l}\text { The time period of the } \\
\text { teaching practice is allocated } \\
\text { and managed able to create } \\
\text { competence and } \\
\text { marketability of the student } \\
\text { teachers }\end{array}$ & 1 & 12.5 & 5 & 62.5 & 1 & 12.5 & 1 & 12.5 & 0 & 0.0 & 2.25 \\
\hline $\begin{array}{l}\text { Our teaching practice } \\
\text { program creates } \\
\text { opportunities for job in the } \\
\text { job market. }\end{array}$ & 1 & 12.5 & 7 & 87.5 & 0 & 0.0 & 0 & 0.0 & 0 & 0.0 & 1.88 \\
\hline
\end{tabular}

Table 2: Employers Rated on the Effectiveness of Teaching Practice Program Relates to Development of Competence and Marketability of University Graduates ( $N=8)$ Source: Field Data (2018)

Table 2 indicates that, (75\%) of the employers perceived that Mwenge teaching practice program was competent based while $(12.5 \%)$ of the employers did not agreed that teaching practice was competent based. Also (75\%) of the employers explain that teaching practice program is marketable while (12.5\%) disagree. 4.22, 50\% showed that employers readily employed some graduates from Mwenge Catholic University after their teaching program was over, this implies that teaching practice creates opportunities for the student teachers to b marketable while $12.5 \%$ of employers did not employ teaching practice student teachers from Mwenge Catholic University after graduation. Also 87.5\% of employers agreed that Mwenge teaching practice program was well manageable however $12.5 \%$ of employers were undecided. From the mean value of (2.38) it shows that teaching practice program is monitored effectively to create competence and marketability while the mean of (1.50) being on the range of the least which described that the teaching practice program was ineffective towards making student teachers marketable. This implies that general management and control of teaching practice program should be improved. Similarly the finding comply with that of (Awofala et al , 2017 and Bolarfinwa, 2014) that indicate that teaching practice has never been a waste of time rather it has helped to inculcate the profession traits in student teachers, preparing them for the real classroom and school situations, The study examined school administrators' perception of the skills central to the marketability of pre-service teachers in order to make them work- ready when they graduates and increase their marketability in the transition from learning to earning.

$75 \%$ of employers agreed that teaching practice is supervised effectively to create competence and marketability of the student teachers while $62.5 \%$ of employers agreed that teaching practice monitoring program is managed effectively to create competence and marketability while $25 \%$ of them disagree, This implies that Mwenge teaching practice program strategy on supervising teaching practice is well arranged and conducted. $62.5 \%$ of employers agreed that the time period of the teaching practice is allocated and managed able to create competence and marketability of the student teachers while that of $12.5 \%$ disagreed. These results are similar to Bolarfinwa (2014) whose findings indicated that At least three weeks of grace should be given to student teachers to get used to the school system before assessment, 
there should be an extension of duration for the teaching practice, lastly adequate orientation should be given to student teachers before teaching practice exercise. However, table 4.23, 87.5\% of employers agreed that Mwenge teaching practice program creates opportunities of the graduates for employment in the job market. While $12.5 \%$ were strongly agreed. This means that the time for the student teachers to take for the practice must be sufficient in order to give them enough time for them to study different challenges in the teaching career. Extended time for the teaching practice for student teacher made them being understood by employers that make them obtain job opportunities easily. The findings corroborated with Bandula's social learning theory which postulate that people learn from one another via observation, imitation and modeling. People learn by observing others behavior, altitudes and outcomes of those behaviors. 'Most human behavior is learned observationally through modeling. From observing others, one forms idea of how new behavior are performed, and on later occasions this coded information as a guide for action' Bandura (1977).

The main participants of the teaching practice program were student teachers, these knew how the program was conducted since they interacted with both the head of the school, monitors, supervisors as well as the students hence Table 3indicate how student teachers identify effectiveness of the teaching practice program toward competence and marketability of the university graduates.

\begin{tabular}{|c|c|c|c|c|c|c|c|c|c|c|c|}
\hline \multirow[t]{2}{*}{ Items } & \multicolumn{2}{|c|}{ SA } & \multicolumn{2}{|c|}{ A } & \multicolumn{2}{|c|}{$\mathbf{U}$} & \multicolumn{2}{|c|}{ D } & \multicolumn{2}{|c|}{ SD } & \multirow[b]{2}{*}{ Mean } \\
\hline & $f$ & $\%$ & $\mathrm{f}$ & $\%$ & $\mathrm{f}$ & $\%$ & $\mathrm{f}$ & $\%$ & $\mathrm{f}$ & $\%$ & \\
\hline $\begin{array}{l}\text { Our teaching practice program } \\
\text { is effective. }\end{array}$ & 47.0 & 47.0 & 48.0 & 48.0 & 1 & 1.0 & 3 & 3.0 & 1. & 1.0 & 1.54 \\
\hline $\begin{array}{l}\text { Our teaching practice program } \\
\text { is effective toward creating } \\
\text { competent teachers. }\end{array}$ & 54.0 & 54.0 & 41.0 & 41.0 & 2.0 & 2.0 & 3.2 & 3.0 & 0.0 & 0.0 & 1.69 \\
\hline $\begin{array}{l}\text { Our teaching practice program } \\
\text { is effective toward making } \\
\text { student teacher marketable. }\end{array}$ & 39 & 39.0 & 56 & 56.0 & 2 & 2.0 & 3 & 3.0 & 0 & 0.0 & 2.01 \\
\hline $\begin{array}{l}\text { The resource used in teaching } \\
\text { practice program are effective } \\
\text { toward creating competent } \\
\text { teachers. }\end{array}$ & 34 & 34.0 & 41 & 41.0 & 15 & 15.0 & 10 & 10.0 & 0 & 0.0 & 2.00 \\
\hline $\begin{array}{c}\text { The teaching practice program } \\
\text { is managed effective in } \\
\text { creating competence and } \\
\text { marketability. }\end{array}$ & 27 & 27.0 & 55 & 55.0 & 11 & 11.0 & 5 & 5.0 & 2 & 2.0 & 2.22 \\
\hline $\begin{array}{l}\text { Teaching practice is supervised } \\
\text { effectively to create } \\
\text { competence and marketability } \\
\text { of the student teachers. }\end{array}$ & 23 & 23.0 & 50 & 50.0 & 12 & 12.0 & 12 & 12.0 & 3 & 3.0 & 2.30 \\
\hline $\begin{array}{c}\text { Teaching practice monitoring } \\
\text { program is managed effectively } \\
\text { to create competence and } \\
\text { marketability. }\end{array}$ & 25 & 25.0 & 40 & 40.0 & 17 & 17.0 & 16 & 16.0 & 2 & 2.0 & 2.65 \\
\hline $\begin{array}{l}\text { The time period of the teaching } \\
\text { practice is allocated and } \\
\text { managed able to create } \\
\text { competence and marketability } \\
\text { of the student teachers. }\end{array}$ & 19 & 19.0 & 35 & 35.0 & 16 & 16.0 & 22 & 22.0 & 8 & 8.0 & 2.40 \\
\hline $\begin{array}{l}\text { Our teaching practice program } \\
\text { creates opportunities for job in } \\
\text { the job market. }\end{array}$ & 28 & 28.0 & 43 & 43.0 & 16 & 16.0 & 10 & 10.0 & 3 & 3.0 & 2.17 \\
\hline
\end{tabular}

Table 3: Student Teacher's Perception on the Effectiveness of Teaching Practice Program in Relations to the Development of Competence and Marketability of University Graduates ( $N=100)$ Source: Field Data, (2018)

The findings in Table 3indicate that $48 \%$ of the student teachers agreed that the teaching practice program is effective, while $47 \%$ strongly agreed and $17 \%$ student teachers disagreed while $1 \%$ student teacher was undecided. Also $54 \%$ of the student teacher strongly agreed that teaching practice program is effective toward creating competent teachers, while $3 \%$ of student teachers disagreed, this indicates that teaching practice is effectively supervised because the higher percentage of the student teachers agreed.

However, Table 3also indicates that $55 \%$ of the student teachers agreed that teaching practice program was managed effectively in creating competence and marketability and $27 \%$ strongly agreed while only $2 \%$ disagreed, $43 \%$ of the student teachers agreed that Mwenge teaching practice program creates opportunities for job in the job market while only $3 \%$ of the student teachers disagreed. A mean value of 2.65 indicates that teaching practice monitoring is managed effectively to create competence and marketability, these findings are similar to that Awofala et al (2007) whose results showed a satisfactory level of pre service teachers' performance during the teaching practice as most administrators were in support of recruiting the pre service teachers in future. Teaching practice were ranked most important next to personal 
attributes for enhancing employability and needing most improvement by pre-service teachers. Hence altogether these findings indicated that lager percent of student teachers agreed on the effectiveness of the teaching practice program and how it contributes to the competence and marketability that could easily obtained after their completion of their studies.

The extent to which teaching practice program influence to competence and marketability. From the interview teaching practice coordinator explain on the effective of the teaching practice as follows. During teaching practice teaching practice is made that gives the prior information on how they will conduct when they will be at the field in their selected schools. Then followed by the introduction of the students to the head of schools then the head of schools give feedback to the University if student teachers are accepted to their schools. Peer observation is made them confident before being monitored then monitoring is made. All these are done to ensure effectiveness in the teaching practice.

Also, according to Zhao and Zhang (2017), The result show that, the result of quantitative data showed that the field teaching practice, pre-service teachers' professional identity increased after the field teaching practice. The result of qualitative data validated and elaborated the results of quantitative data in more details with regard to change in professional identity. Specifically, compared with before the field teaching practice, intrinsic value identity including work content, work pattern and other values increased and extrinsic value identity include work environment, income and social status did not significantly change after experiencing teaching practice. The result of qualitative data also showed that mentor support at field school promoted the development of pre-service teachers' professional identity. The development of pre-service teachers' professional identity during field teaching practice further promoted their professional commitment. The implication of this is that, teaching practice seen to have advantages to the student teachers because is the way on which student teachers are imparted with the professional career of education as well as the competence because it exposes them to real life situation of teaching career.

\subsection{What Is the Perception of Employers toward The Effectiveness of the Teaching Practice Program on the Competence and} Skills Developed?

To investigate the perception of employers toward the effectiveness of the teaching practice program on the competence and skills developed different employers from different eight school sampled were rated and the finding is as shown table 22

\begin{tabular}{|c|c|c|c|c|c|c|c|c|c|c|c|}
\hline \multirow[t]{2}{*}{ Items } & \multicolumn{2}{|c|}{ SA } & \multicolumn{2}{|c|}{$\mathbf{A}$} & \multicolumn{2}{|c|}{$\mathbf{U}$} & \multicolumn{2}{|c|}{ D } & \multicolumn{2}{|c|}{ SD } & \multirow[b]{2}{*}{ Mean } \\
\hline & $\mathbf{f}$ & $\%$ & f & $\%$ & $\mathbf{F}$ & $\%$ & f & $\%$ & f & $\%$ & \\
\hline $\begin{array}{l}\text { Mwenge teaching } \\
\text { practice program is } \\
\text { competent based. }\end{array}$ & 1 & 12.5 & 6 & 75.0 & 0 & 0.0 & 1 & 12.5 & 0 & 0.0 & 2.13 \\
\hline $\begin{array}{l}\text { Mwenge teaching } \\
\text { practice program is } \\
\text { marketable. }\end{array}$ & 1 & 12.5 & 6 & 75.0 & 1 & 12.5 & 0 & 0.0 & 0 & 0.0 & 2.00 \\
\hline $\begin{array}{l}\text { We employ teaching } \\
\text { practice student es from } \\
\text { MWECAU easily after } \\
\text { their teaching program. }\end{array}$ & 2 & 25.0 & 4 & 50.0 & 1 & 12.5 & 1 & 12.5 & 0 & 0.0 & 2.13 \\
\hline $\begin{array}{c}\text { Mwenge teaching } \\
\text { practice program is well } \\
\text { manageable. }\end{array}$ & 0 & 0.0 & 7 & 87.5 & 1 & 12.5 & 0 & 0.0 & 0 & 0.0 & 2.13 \\
\hline $\begin{array}{c}\text { Mwenge student } \\
\text { teachers are competent. }\end{array}$ & 0 & 0.0 & 7 & 87.5 & 1 & 12.5 & 0 & 0.0 & 0 & 0.0 & 2.13 \\
\hline $\begin{array}{l}\text { Mwenge student } \\
\text { teachers are } \\
\text { marketable. }\end{array}$ & 1 & 12.5 & 5 & 62.5 & 0 & 0.0 & 2 & 25.0 & 0 & 0.0 & 2.38 \\
\hline $\begin{array}{c}\text { Mwenge student } \\
\text { teachers have all mind } \\
\text { developed teachers. }\end{array}$ & 0 & 0.0 & 4 & 50.0 & 0 & 0.0 & 4 & 50.0 & 0 & 0.0 & 3.00 \\
\hline $\begin{array}{l}\text { Mwenge student } \\
\text { teachers are } \\
\text { resourceful. }\end{array}$ & 1 & 12.5 & 7 & 87.5 & 0 & 0.0 & 0 & 0.0 & 0 & 0.0 & 1.88 \\
\hline $\begin{array}{l}\text { Mwenge student } \\
\text { teachers improve our } \\
\text { school. }\end{array}$ & 0 & 0.0 & 7 & 87.5 & 1 & 12.5 & 0 & 0.0 & 0 & 0.0 & 1.87 \\
\hline
\end{tabular}

Table 4: Employer Rating on the Perception of Employers Toward Effectiveness of Teaching Practice Program on the Competence and Skill Developed. $(N=8)$

Source: Field Data, (2018)

Table 4indicate that $75 \%$ of the employers agreed that Mwenge teaching practice program is competency based while $12.5 \%$ disagreed. $75 \%$ of the employers agreed that Mwenge teaching practice program is marketable while $12.5 \%$ were strongly agreed by the employers and most of the employers (50\%) indicated that they employ teaching practice students from MWECAU easily after their teaching program while $12.5 \%$ they does not employ university graduates from MWECAU while the mean value from Table 4indicate that mean of (3.00) indicated that Mwenge student teachers have all 
mind developed teachers and mean of (1.87) show that they employ Mwenge student teachers to their schools. Similarly (Awofala et al, 2017) results indicated satisfactory level of pre service teachers' performance during the teaching practice as most administrators were in support of recruiting the pre service teachers in future. This implies that teaching practice program creates much opportunity to the student teachers since administrators exposed to much of the experience of the student teacher and their ability to the teaching skills. Then enables them to easily being employed.

Also, Table 4indicates that $87.5 \%$ of employers agreed that Mwenge student teachers are competent while that of $12.5 \%$ undecided, on the other hand $87.5 \%$ of employers agreed that Mwenge student teachers are resourceful and $12.5 \%$ strongly agreed. The resourceful of the student teachers was due to their competence that made them very potential in the schools. This implies that employers gave much priority to the teaching practice program since it was effectively conducted and developed the student teacher's competency, skills and marketability that made them resourcefully and potential.

\subsection{Hypothesis Testing}

This study sought to investigate the relationship between the variables under the study. t-test with 0.05 level of significant were used to test hypotheses. One hypothesis stated from null hypotheses $(\mathrm{Ho})$ was tested.

Ho 1 There is no relationship between teaching practice and competence and marketability

\subsection{Decision Rules}

Given a significance level of 0.05 a non- directional test,

- If the observed significance level (P- value) $<0.05$ significance level, reject null hypothesis $\left(H_{o}\right)$.

- If the observed significance level (P-value) $\geq 0.05$ significance level, do not reject the null hypothesis $\left(H_{o}\right)$.

The Table 5 shows how hypothesis was used to test the relationship between teaching practice and marketability of the university graduates where t-test was used.

\begin{tabular}{|c|c|c|c|c|c|c|c|}
\hline \multicolumn{9}{|c|}{ Paired Samples Statistics } & t & df & $\begin{array}{c}\text { Sig(2- } \\
\text { tailed) }\end{array}$ \\
\hline \multicolumn{1}{|c|}{} & Mean & $\mathrm{N}$ & $\begin{array}{c}\text { Std. } \\
\text { Deviation }\end{array}$ & & & .000 \\
\hline $\begin{array}{c}\text { Mwenge teaching practice } \\
\text { program is effective }\end{array}$ & 1.53 & 30 & .571 & -6.496 & 29 & \\
\hline $\begin{array}{c}\text { The teaching practice } \\
\text { program is managed } \\
\text { effective in creating } \\
\text { competence and } \\
\text { marketability }\end{array}$ & 2.43 & 30 & 1.040 & & & \\
\hline
\end{tabular}

Table 5: Independent Sample Test for Means of Measuring the Relationship between

Teaching Practice and Competence and Marketability

Source: Field Data, (2018)

- $\mathrm{H}_{1}$ : There is a relationship between teaching practice and competence and marketability

- $\mathrm{H}_{0:}$ There is no relationship between teaching practice and competence and marketability

T-test was used to determine whether teaching practice has significant relationship with a competence and marketability during teaching practice program. The results of the analysis summarized in Table 4.28 shows that there was significant difference in Mwenge teaching practice program is effective $(\mathrm{X}=1.53, \mathrm{SD}=.571)$ and the teaching practice program is managed effective in creating competence and marketability $[\mathrm{X}=2.43, \mathrm{SD}=1.040 ; t(29)=-6.496, p=.00]$. Therefore, since $(\mathrm{p}<.05)$ null hypothesis was rejected and the study concluded that there was significant relationship between teaching practice and competence and marketability to the graduates. The findings imply that teaching practice has something to do in competence and marketability to university graduates. The findings corroborated with the findings reported by Awofala et al (2017) that teaching practice were ranked most important next to personal attributes for enhancing employability and needing most improvement by pre-service teachers.

\section{Conclusion}

The findings indicate that the management of the teaching practice program contributes to competence building; because it brings about personality identity, control discipline, time management and interrelationship. The teaching practice on pre-service teachers; their competences and marketability increased after the field teaching practice. This is evidenced that most of the student teachers were agreed that teaching practice program is effective and develop competence and marketability of university graduates. The student teachers' minds were fully developed similar to those of the employed teachers; because they had managerial skills and teaching experiences. There is a satisfactory level of preservice teachers' performance during the teaching practice as most administrators were in support of recruiting the preservice teachers in future. The teaching practice program is market oriented towards development of competence and marketability of graduates; because they are equipped with technical skills and being competent.

Student teachers perceive teaching practice as an important tool of learning to teach because it promotes development of teaching experiences and prepared them for the real world of work mean value (3.87) teaching practice program is market oriented that develop competence and marketability of university graduates. 
There effective monitoring of the teaching practice program towards creating competence and marketability to university graduates. teaching practice programs and supervision differs from one university to another in term of periods, goals, methods of assessment, evaluation process, the nature and structure of the teaching practice programs may have an influence on the competence and marketability of graduates. Therefore, management and monitoring of teaching practices enable student teachers to cope with teaching professional career from their monitors, supervisors and employed teachers after feed-backing them with required skills towards teaching.

Employers' perception is high towards teaching practice program by suggesting the development of graduates' mind as that of employed teachers; this enable student teachers to be familiar with the teaching professional and challenges that employed teachers faced and how they solved them. Teaching practice program offered is marketable; because it equips graduates with the required skills and techniques that enable them to suit the demand of the market. mean value (3.87)

Student teachers perceived teaching practice as an important tool of leaning to teach because it promoted the development of teaching experience and prepare them for the real world of work easily. Having the program that equip skills to student teachers; it enables most of learners in lower studying levels to focus on those universities that are marketable which could later enable them to be employed after graduating.

Categorization of graduates also affected their employment status such self-employed and unemployed. However, the findings indicate that employability can be enhanced through individual's engagement in employability skills development program (ESPD) activities which subsequently foster one's employability skills. Hence, other skills (apart from the contents from the class) the graduates must have different soft skills that will offer them extra advantages to differentiate one graduate to another.

\section{Recommendations}

In the involvement of the study findings, recommendation was made in order to facilitates development of competence and marketability of university graduates following the effectiveness of teaching practice programs. There should be a 're-think' about what happens to pre-service teacher education with reference to when inexperienced teachers enter into teaching in order to help them smoothly 'initiated' and adapt to the teaching profession. Universities should prepare competitive programs that could equip student teachers with skills and competencies that identify with the market needs as well as the university market recognition. Also, both government and university management should develop clear structures clear for field practices that relates to the support of student employability. Universities should develop curriculums that are flexible in order to create time for student teachers to develop the skills and experiences through part time jobs which will improve their market value and employment.

\section{References}

i. Awofala, O.A. et al (2017). School administrators' perceptions of the employability of pre-service science, Technology and Mathematics teachers through teaching practice, Lagos state, University Publishers.

ii. Bebbie, E.R. (2010). The practice of social research (12 ${ }^{\text {th }}$ Edition), USA: Wadsworth cengage Publishing desk.

iii. Bolarfinwa, O. (2014), Effectiveness of teaching practice on student teachers in tertiary Institutions in Nigeria. Lagos: LIU Limited Publishers.

iv. Msangya, B.W. et al (2016), Teaching practice experience for undergraduate student teachers, Sokoine university of Agriculture. Morogoro, Sokoine University Publishers.

v. Iktde, G.A. and Ado, I.B. (2015), Attitude of students toward teaching practice exercise in Nigeria University, A case study of University of Uyo, Akwa Ibom: Uyo University Press.

vi. Katherine and Fulgence, (2016). Employability of higher education institution Graduates, Dar es salaam: Dar es salaam University College of Education (DUCE) Publishers.

vii. Kiggundu, E. and Nayimuli, S. (2009). Teaching Practice: A Make or Break Phase for Student Teachers. Cape town: South African journal of Education Limited.

viii. Koross, R. (2016). The Student Teachers "Experiences during Teaching Practice and It's Impact on their Perception of the Teaching Profession. Eldoret: IRA International Journal of Education and Multidisciplinary Studies Publishers.

ix. Kothari, R. (2004), Research methodology, Method and Techniques, $2^{\text {th }}$ Edition, New Delhi: International Publishers India.

x. Komba S.C and Kiria E.S. (2013), The effectiveness of teaching practice in improving student teachers' teaching skills, Morogoro: Sokoine University of Agriculture Publishers.

xi. Mannathoko, M.C. (2013). 'Does Teaching Practice Effectively Prepare Student-Teachers to Teach Creative and Performing Arts?' Gaborone: Botswana University Press.

xii. McClelland, D and Burnham, D (2001). Power is the greater motivator, Cambridge: Harvard Business Review Limited.

xiii. $\quad$ Mkandawire, M.T et al (2016). What Mismatch Challenges between What Teacher Education Institutions Teach and What is Expected at Work Place? Retrospective Views of Secondary School Teachers from Tanzania and Malawi Studying in China, Hong Kong: Central China Normal University Press.

xiv. Omari, I. M. (2011), Concepts and methods in education research, Dar es salaam, Oxford University Press (T) Ltd.

XV. Omari, I.M (2011), Concepts and methods in education research, Dar es salaam: Oxford University Press (T)Ltd.

xvi. $\quad$ Rakesh, R. (2013).' A study of practice teaching practice; A transition phase for student teachers' voice of Research Publishers. 
xvii. Komba, S.C. (2013), The effectiveness of teaching practice in improving student teachers' teaching skills in Tanzania, Morogoro: Sokoine University of Agriculture Press.

xviii. Mohdi, S.B. (2015), Teaching practice in enhancing student teachers speaking competence, Shah alam: University Technology Mara Limited.

xix. URT (2007), Basic statistics in education Tanzania (BEST), 2002-2006 National data, MOEVT, Dar es salaam. National Bureau of Statistical Publishers

xx. Wambugu, P. et al (2013). Student teachers' perceptions of teaching practice assessment, Nairobi: Egerton University Press.

xxi. Zhao, H. and Zhang, X. (2017). The influence of field teaching practice on pre-service teachers' professional identity, Beijing, Beijing Normal University Publishers. 